\title{
Analysis of the Influence of the "The Belt and Road" Strategy on China's Foreign Trade under the Big Data Era
}

\author{
Ran Zhang, Xiang Li \\ Administrative Engineering College, Zhengzhou University, No.100 Science Avenue, Zhengzhou, \\ China
}

Keywords: big data, “The Belt and Road” strategy, foreign trade

\begin{abstract}
In recent years, the big data technology has emerged as the times require with the development of the Internet and information technology, and its rapid development and application have brought about earth-shaking changes in social life. In the process of promoting the "The Belt and Road" strategy in China, how to use big data effectively to seize opportunities, meet challenges, and seek a more appropriate mode of foreign trade development has also become an important issue. The purpose of this paper is to analyze how Chinese foreign trade companies can play a comparative advantage in the era of big data, improve the foreign trade environment, improve the pertinence and scientificity of decision-making, accelerate product innovation, and promote industrial structure upgrading. At the same time, timely response is given to the existing risks arising from big data analysis, and an early warning mechanism is established to avoid risks.
\end{abstract}

\section{Introduction}

The 21st century is an era of informationization and intelligence. With the application and popularization of the Internet, information plays an increasingly important role in people's production and life. Big data technology emerges at the historic moment, and its emergence is also a social life. Brought more rapid changes. The current world pattern is complicated, regional economic development is unbalanced, unilateral trade recovery, energy shortage, cultural conflicts and many other factors make the development problems faced by countries still serious. The international investment and trade pattern and multilateral investment and trade rules are brewing profoundly, and the "Building" All the way to promote the orderly and free flow of economic factors, efficient allocation of resources and deep integration of markets, promote economic policy coordination among countries along the route, apply big data technology to improve the scientific and policy effectiveness of the corresponding decision-making, and enable the scope of regional cooperation. More extensive, higher level, and deeper. The participating countries and organizations of the "Belt and Road" will work together to create an open, inclusive, balanced and inclusive regional economic cooperation framework that is in line with the fundamental interests of the international community and demonstrates the common ideals and beautiful pursuits of human society. It is international cooperation and global governance. Active exploration of the new model. 
The "Belt and Road" brings opportunities for China's foreign trade development, and it is accompanied by challenges. We should seize opportunities with a positive attitude and meet challenges with scientific and effective decision-making.

\section{Introduction to big data}

\subsection{The concept of big data}

The earliest presentation of "Big Data" was proposed in 1980, Victor Meyer Schonberg and Kenneth Cookee proposed the definition of big data in the "Big Data Age", in order to make information more realistic and reliable. Instead of taking the shortcut of sampling surveys, we use a more cumbersome method to analyze all the data. The term was first applied to Apache's open source project, Nutch, to express a large number of data sets generated by batch processing or analysis of web search indexes.

Today, big data is the technology that quickly obtains valuable information from a wide variety of types of data. The core of solving big data problems is big data technology(Zhang Lanting,2014). The current "big data" refers not only to the size of the data itself, but also to tools, platforms and data analysis systems for collecting data. The goal of big data research and development is to develop big data technology and apply it to related fields to promote its breakthrough development by solving huge data processing problems. Therefore, the challenges brought by the era of big data are not only reflected in how to deal with huge amounts of data to obtain valuable information, but also in how to strengthen the research and development of big data technology and seize the frontier of the development of the times. Ma Yun, founder of Alibaba, mentioned in his speech that the future era will not be the IT era, but the era of DT, which is Date Technology data technology. Big data can better integrate analytical data, accurately predict and avoid risks. Decisions in terms can provide an effective basis.

\subsection{Characteristics of big data}

Based on Lenny's theory, IBM proposes 5V features of big data: Volume, Velocity, Variety, Value, Veracity, and it is considered the most comprehensive features of big data.

1) Volume: It can scale from hundreds of terabytes to tens of hundreds of PBs and even EBs. A variety of portable communication devices, Internet of Things and cloud computing, cloud storage and other technologies, all traces and behaviors of people and things can be recorded, resulting in a large amount of data.

2) Variety: There are many types of data, including various formats and forms, including not only traditional formatted data, but also text, pictures, videos, geographic locations and other information from the Internet. Big data provides the possibility to handle diversified data from different sources and individuals, which is the power of big data.

3) Velocity: that is, many big data needs to be processed in a timely manner within a certain time limit. Big data is an advanced technology characterized by real-time data processing and real-time result orientation. For data processing speed, it is required to follow the "1 second law", that is, to give analysis results in the second time range, beyond this time, the data The value will be greatly reduced and there will be no technical advantage.

4) Veracity: The result of the treatment must guarantee a certain accuracy. The importance of data lies in providing critical information for decision-making. Scale alone cannot be the basis for decision-making. The authenticity and reliability of data are important factors influencing decisionmaking.

5) Value: Big data contains a lot of deep value. It can bring huge commercial value by analyzing 
and utilizing real-time control of market changes and consumer preferences.

\section{Introduction of the "Belt and Road" strategy}

\subsection{Overview of the "Belt and Road” strategy}

In the fall of 2013, Chinese President Xi Jinping proposed the cooperation initiative of building the "New Silk Road Economic Belt" and the "21st Century Maritime Silk Road", which was recognized by the international community and the leaders of many countries responded positively. The "Belt and Road" fully relies on the existing dual and multilateral mechanisms of China and relevant countries, and further develops and deepens cooperation through the existing and effective regional cooperation platform. The "Belt and Road" aims to use the historical symbols of the ancient Silk Road, follow the path of peaceful development, and actively develop economic partnerships with countries along the route. The construction of "The Belt and Road" conforms to the common aspirations and interests of all countries along the route. All parties to the cooperation have a grand economic vision. We need all countries to cooperate sincerely, and to achieve mutual benefit and win-win, long-term security and long-term cooperation with the concept of "communicating, building and sharing". The goal is to go hand in hand. The effective implementation and efforts of the " The Belt and Road " strategy will have a far-reaching impact on the international structure and domestic development, and will become a new lever for instigating China's rise(Baidu Encyclopedia of The Belt and Road).

\subsection{Development Status of the "The Belt and Road" Strategy}

The 2018 "Belt and Road" Trade Cooperation Big Data Report focuses on the status quo and trend forecast of "One Belt and One Road" trade cooperation. On the basis of continuing the overall layout of last year's report, it aims to present China and the "clear areas" in a clearer, more comprehensive and in-depth manner. All the way, the latest characteristics and trends in regional cooperation, domestic provinces, autonomous regions and municipalities, cooperation with the “Belt and Road” countries, and “The Belt and Road” trade commodity structure (Shi Yong, 2016).

The report includes statistics on 71 "Belt and Road" countries and 31 provinces/autonomous regions/municipalities in Mainland China. For the first time, seven countries including South Korea, Panama, South Africa, New Zealand, Madagascar, Morocco and Ethiopia are included in the statistics. The report comprehensively uses a variety of big data analysis methods such as data mining, cluster analysis, and data visualization. The types of basic trade products and data volumes that have been called have increased significantly, reaching more than 8,500 categories and 270 million, and are fully presented in the form of an appendix. Various basic data for querying. The report comprehensively and objectively analyzes the overall pattern of the "Belt and Road" trade cooperation in 2017, China and the "Belt and Road" countries, and China's provinces, autonomous regions and municipalities, from the bilateral trade volume, trade commodities, trade entities, trade methods, and cooperation models. The status and development of trade cooperation with the "Belt and Road" countries.

\subsection{Prospects for foreign trade development in the "Belt and Road" Strategy}

The "Belt and Road" runs through the Asia-Europe and non-continental continents. One is the active East Asian economic circle, and the other is the developed European economic circle. The vast economic development potential of the vast hinterland countries is huge. According to the "One Belt and One Road" trend, the land relies on the international channel, supported by the 
central cities along the line, and the key economic and trade industrial parks as the cooperation platform to jointly build an international economic cooperation corridor; the sea is a key port as a node to jointly build a safe and efficient Transport large passages. The two economic corridors of China, Pakistan, Bangladesh, China, and Myanmar are closely related to the promotion of the "Belt and Road" construction. It is necessary to further promote cooperation and make greater progress. The implementation of the "The Belt and Road" strategy has spurred closer economic and trade exchanges between China and countries along the route. In order to develop from their own development, the countries along the line have also enthusiastically responded to the "The Belt and Road" initiative, and the willingness to cooperate has also brought about a broader market and development space.

According to the 2017 data of China Belt and Road Network, in the middle of 2017, the railways of China and Europe have nearly 7,000 trains, 57 operating lines, 35 domestic driving cities, and 34 cities in 12 countries in Europe. In terms of aviation, as of May 2017, China's civil aviation has achieved direct air travel with 43 countries along the route; foreign airlines have opened 18 new national routes along the "Belt and Road" route. In terms of port and maritime logistics, as of May 2017, China has signed bilateral maritime agreements (river agreements) with 36 countries along the route and the European Union's 'ASEAN. As of November 2017, the national public transport platform for transportation and logistics has been realized globally. The logistics information of 31 ports is interconnected and shared. In terms of cross-border optical cable, China has established 34 cross-border road cables and several international submarine cables with 12 countries along the route; on December 3, 2017, at the 2nd World Internet Conference, China and Laos, Saudi Arabia, Serbia, Thailand The relevant departments of Turkey, the United Arab Emirates and other countries jointly launched the " The Belt and Road " Digital Economy International Cooperation Initiative. In the first three quarters of 2017, imports and exports along the "Belt and Road" countries increased by 20.1\%; for Russia, India, Malaysia and other countries to maintain rapid growth. In the first three quarters, the number of newly established enterprises in China was 2,893, an increase of 34.4\% over the same period of last year, and the actual investment was US $\$ 4.24$ billion. China has signed various investment and trade agreements with 58 countries; the "single window" comprehensive simplification rate reached 59 \% (China Belt and Road Network).

With the increase in cooperation between the participating countries of the "Belt and Road", the logistics and transportation system has become more perfect, and the economic development potential has gradually released. China's foreign trade will continue to grow steadily and become a new fulcrum for China's economic growth.

\section{The impact of big data on foreign trade in the "Belt and Road"}

\subsection{Improve the pertinence and scientificity of decision-malking}

The "Belt and Road" covers a large number of countries and international organizations, and the national and political bodies are different, and the level of economic development is uneven. In the process of "The Belt and Road" strategy, a large amount of data of various types will inevitably be generated. How to extract and release hidden and decision-making information from these data is particularly important.

In the new economy, data has become an important asset for companies, even core assets. In the face of the "The Belt and Road" emerging market, the first thing foreign trade enterprises need to do is to use the big data to explore potential business opportunities in the local market, discover new business highlights, and enhance product competitiveness. With big data, you can provide strong data support and reference for decision making. The "The Belt and Road" big data analysis service mainly uses the big data analysis technology to track the progress of "One Belt and One Road" 
cooperation between China and the countries along the line in a timely and accurate manner, providing real-time and predictive data support and consulting services for the government and enterprises to promote The related policies and measures and investment cooperation behaviors of the "Belt and Road" are more targeted and scientific.

\subsection{Enhance the export competitiveness of e-commerce products and promote the internationalization of the RMB}

Almost all of the important cities in the "The Belt and Road" domestic strategic route have laid out the business content of cross-border e-commerce. The export commodities of cross-border ecommerce in China are all superior products in the traditional Chinese foreign trade industry. From the perspective of buyer demand and seller demand, the development of cross-border e-commerce is an inevitable choice for China's foreign trade export industry. Under the background of "The Belt and Road", the government has led the construction of cross-border e-commerce trade rules, and the construction of cross-border e-commerce credit system has been further developed, which has a great driving effect on China's export trade (Xu Jing, 2017).

In the context of the new situation of international trade, e-commerce, as a new way of trade settlement, provides opportunities for RMB-denominated transactions with its low cost and high efficiency, which can greatly increase its proportion in regional trade. With the gradual increase in the share of China's import and export trade and the rapid development of cross-border e-commerce, import and export enterprises and individuals through cross-border network consumption, transfer, remittance and other functions in cross-border electronic payment systems through third-party payment platforms will be widely used. This will inevitably lead to more frequent economic and trade exchanges between China and Central Asian countries, and thus promote the internationalization of the RMB (Li Honghan, 2015).

\subsection{Accelerate product innovation and promote industrial structure upgrading}

The "The Belt and Road" strategy is proposed to accelerate the product innovation of China's export enterprises, adjust product mix and promote industrial upgrading. For a long time, as a developing country, China's export products are mostly concentrated in labor-intensive products and low-cost, low-value-added cheap products. However, with the implementation of the Belt and Road Initiative, Chinese enterprises and enterprises along the line of the country are more closely connected. More actively and fully attracting and utilizing foreign capital, promoting the technological progress of China's foreign trade enterprises, the demand for some high-end technology products, especially communication equipment, has increased rapidly, which has promoted the optimization of China's export industry structure and ushered in the "Belt and Road" strategy. China's industrial upgrading.

Through the big data platform for information collection and analysis, integrate superior resources, promote exchanges and cooperation between different industries and different fields, give full play to the coordination and supervision of industry associations, and further standardize market order. China's foreign trade enterprises must master more advanced technologies to produce higher value-added products, thereby improving product differentiation and competitiveness. In this way, on the one hand, it can prevent China's products from being subjected to anti-dumping investigations due to low prices; on the other hand, it can promote China's industrial upgrading. In order to meet this requirement, China's foreign trade enterprises must strengthen scientific research and innovation, and develop products with higher technological content. In the era of economic globalization, it is an important and feasible measure for China's foreign trade enterprises to deal with trade friction by integrating internal and external resources of enterprises to bypass various 
trade barriers. Especially in the process of "The Belt and Road" strategy, China's ties with neighboring countries have become increasingly close, providing technical cooperation and interconnection possibilities for many industries and fields. Chinese enterprises must seize this opportunity to deepen their foreign the understanding of trade policy, access to technology and brand through overseas mergers and acquisitions, and accelerate the upgrading of industrial structure.

\subsection{Financial innovation accelerates and overseas investment increases}

With the implementation of the "The Belt and Road" strategy, a large amount of infrastructure and other construction investments require a large amount of capital. The corresponding financial services have gradually increased (Wang Wenhao, 2017). According to the statistics of the National Bureau of Statistics, the total number of members of the AIIB has increased to 84, 42 of which are countries along the line, and more than 20 investment projects have been approved, totaling more than US\$3.7 billion. The Silk Road Fund has signed 17 projects with a commitment to invest \$7 billion and supports a total investment of $\$ 80$ billion. Six Chinese banks have established more than 80 branches, sub-branches and representative offices in 19 countries along the route; China UnionPay cards cover more than 50 countries along the line, more than 4 million merchants and 400,000 ATMs. China Export Credit Insurance Corporation provides various types of insurance services for cooperation projects in 20 countries along the line, and signed cooperation agreements with Belarus, Georgia and other countries. Since risk management is one of the essence of finance, and risk control is the core of all financial services, the construction of financial business risk prevention and control system based on big data technology is also the focus of cooperation in the field of financial services (Dong Hong, Lin Huihui, 2015).

With financial cooperation, foreign trade enterprises can acquire R\&D capabilities, build international brands and explore foreign markets through mergers and acquisitions and foreign investment, and improve the international competitiveness of products. In addition, foreign direct investment of foreign trade enterprises can also enjoy national treatment and obtain more favorable export conditions, thus effectively bypassing local trade remedy measures against China and gaining advantages when exploring the international market. At the same time, enterprises can invest in building products to produce goods, and they can learn more about the local market, analyze consumer shopping data through big data, strengthen targeted design of products, cater to local market demand, and improve product competitiveness. .

\subsection{Establish an early warning mechanism to avoid risks and reduce friction}

With the rapid growth of foreign trade, China has faced greater trade frictions and financial risks while achieving excellent results in the transformation and upgrading of major trading countries to trading powers.

The implementation plan of railways, highways and other transportation facilities in the "Belt and Road" strategy can provide a platform for Chinese enterprises to invest in foreign direct investment. Financial cooperation and international trade programs can provide channels for foreign direct investment. Effective foreign direct investment is not only conducive to reducing the scale of China's exports, alleviating the long-term surplus of China's foreign trade, reducing the hostility of trading partners to China's foreign trade, thereby reducing foreign trade friction complaints, but also transferring domestic surplus production capacity and improving corporate international Degree(Meng Lingxiu,2017). Through foreign direct investment, Chinese enterprises can also bring more employment opportunities to target countries, thereby alleviating the trade friction caused by a large trade surplus and effectively avoiding trade disputes. In the process of cooperation with 
foreign enterprises, Chinese enterprises can obtain basic knowledge about new technologies through personnel flow and information diffusion, and on this basis, through independent research and development to achieve product technology spillover effects and improve product technology content, Improve the ability of companies to resist risks.

In the construction of the "Belt and Road" initiative, China officially established the AIIB in 2015 in order to support the infrastructure construction of the countries along the route. The establishment of the AIIB is conducive to Asian countries to export capital projects, reduce costs, and enhance the conversion of capital investment and infrastructure. At the same time, the Asian Development Bank, which is dominated by the United States and Japan, has been threatened, and the trade friction will be more confronted with financial friction in the form of money. The construction of the AIIB has certain positive significance for the advancement of the RMB internationalization process. However, the instability of the RMB currency has also aggravated the financial friction between China and neighboring countries' capital projects, which poses a corresponding threat to the construction of the "Belt and Road" and foreign trade.

In order to enhance the early warning and response capabilities of international trade risks, the industry should unite and help each other, share information, and establish a unified, efficient and scientific international trade friction response mechanism and early warning system based on the big data information platform. Second, efforts should be made to change the mode of export growth, to maximize the technological content of China's export products, and to open up a wider international market. And it is necessary to establish and improve the trade friction response mechanism of the three divisions of labor, government and intermediary organizations.

\section{Conclusion}

The "Belt and Road" strategy aims to promote the orderly and free flow of economic factors along the road, the efficient allocation of resources and the deep integration of the market, and jointly create an open, inclusive and balanced new regional economic cooperation framework. Under this new framework, efforts will be made to promote China's domestic advantageous industries to move toward the high-end of the global industrial value chain, and continuously strengthen China's dominant influence on the regional economic cooperation process, providing new opportunities for China's international trade development. On the other hand, the international environment is becoming more and more complex, and the geopolitical complexity along the line has also brought challenges to the development of international trade. It is accompanied by more trade frictions and financial risks while carrying out extensive economic cooperation. The state and enterprises should carry out all-round cooperation, use new technologies such as big data and cloud computing to promote the implementation of the "The Belt and Road" strategy, promote the development of the national economy, and reduce the economic losses of the state and enterprises in international trade frictions, effectively reducing financial risk.

\section{References}

[1] Baidu Encyclopedia of The Belt and https://baike.baidu.com/item/\%E4\%B8\%80\%E5\%B8\%A6\%E4\%B8\%80\%E8\%B7\%AF/13132427?fr=aladdin

[2] China Belt and Road Network: https://www.yidaiyilu.gov.cn/

[3] Dong Hong, Lin Huihui. The Change of China's Foreign Trade Pattern and the Prevention of Trade Friction under the "The Belt and Road" Strategy [J].China Circulation Economy, 2015, 29(05):119-124.

[4] Li Honghan. The Opportunity of E-commerce Foreign Trade and the Internationalization of RMB in the "Belt and Road” Strategy [J].Gansu Finance, 2015(10):44-47.

[5] Meng Lingxiu. Analysis of China's Countermeasures against International Trade Friction under the "Belt and Road" Situation [J]. Shopping Modernization, 2017(13): 30-31. 
[6] Shi Yong. Big Data and the "The Belt and Road” Strategy [J]. Administrative Management Reform, 2016 (09): 4649.

[7] Wang Wenhao. Opportunities, obstacles and countermeasures of China's foreign trade under the "Belt and Road" [J]. China Business Theory, 2017(21): 59-60.

[8] Xu Jing. The "Belt and Road” Opportunities and Challenges of China's Foreign Trade [J]. China Foreign Capital, 2017 (01): 48-49.

[9] Zhang Lanting. Social Value and Strategic Choice of Big Data [D]. CPC Central Party School, 2014. 